\title{
山形県Y市小学校給食献立の使用食品および調理方法に関する研究
}

\author{
田村 朝子* · 木下 伊規子** \\ (*県立米沢女子短期大学 $\quad * *$ 中京女子大学 $)$
}

\section{Studies on Materials and Cooking Methods of School Lunch Menu in the Y City of Yamagata Prefecture}

\author{
Asako Tamura*, Ikiko Kinoshita** \\ *Yonezawa Women's College of Yamagata Prefecture, 6-15-1, Tohrimachi, Yonezawa, \\ Yamagata, 992-0025 \\ ${ }^{* *}$ Chukyo Women's University, 55, Nadakayama, Yokonecho, Obu, Aichi, 474-0011 \\ *厂992-0025 山形県米沢市通町6-15-1 \\ ** $\bar{\top} 474-0011$ 愛知県大府市横根町名高山 55
}

\begin{abstract}
The Structure of the school lunch menu with respect to choices and cooking method was analyzed for a 3-fiscal-year $(1989,1994$, and 1998) peliod at an elementary school in the $\mathrm{Y}$ city of Yamagata prefecture.

1 ) There was very little difference in the menu number (the food service execution days) over the 3 year peliod. The Japanese menu was almost $50 \%$ of the menu for each fiscal year. The nutrition intake has approximately satisfied the standard quantity.

2 ) One typical menu averaged 22-25 pieces of food and a dish averaged 4.4-4.9 types. The foods ueed the most were seasonings and vegetables. The typical foods were 'milled rice"bread' and 'pork' and these foods were considered staple foods or a main vegetable. 3 ) With respect to the type of cooking methods, it incresaed in comparison from the menu in fiscal 1988 to the menus in fiscal 1994 and 1998.
\end{abstract}

\section{1. 諸言}

日本の学校給食は, 明治22年（1889年）山形県鶴岡町 の私立忠愛小学校において, 鶴岡町と周辺の僧侶によっ て貧困児童を対象に行われた昼食給食が始まりである1) といわれている。その後学校給食は, 昭和27年 (1952年) に学校給食法が制定されて以来, 児童·生徒の体位向上, 栄養改善を目的に実施されており, その形態も, 戦後の 牛乳のみを提供するミルク給食から, 主食（パンをたは 米飯）と牛乳, 副食としてのおかずを提供する完全給食
へと変化してきている。完全給食を実施している小学校 は, 給食を実施している小学校の $98 \%$ にも及んでおり2), その食事内容は，昭和51年（1976年）に「食事内容の多 様化を図り，栄養に配慮した米飯の正しい食習慣を身に つけさせるのに教育上有意義である」3）として，主食と してのパンに加え，米飯給食を正式に導入するようにな ってからは, より多様化してきている。

一方現在の日本人の食嗜好は, 昭和 40 年代ごろから， 高度経済成長に伴う輸入食品の増加やファーストフード チェーンの出現などによって次第に洋風化しており, 児 
童·生徒の好きな料理にもスパゲティ，ハンバーグとい ったカタカナ料理が並ぶようになり，「魚嫌い」も増え ている4,5)。さらに，スナック菓子やファーストフード, 加工食品の摂取も増加している6,7)。国民栄養調査結果 ${ }^{8)}$ から, エネルギー, タンパク質, 脂質の過剒摂取が明ら かになっているが, 洋風料理やファーストフード, 加工 食品などの摂取増加もその一因であると考えられる。ま た, 児童・生徒の体位が年々向上している ${ }^{9,10)}$ が，その 反面, 肥満傾向児も増加 ${ }^{11 \sim 18)}$ し, 虫歯やアレルギー, 各種疾患や病気ではないが何かおかしいという疾患に近 い症状を訴える児童・生徒も増加している19,20)。したが って，これからの学校給食には，こういった疾患などへ の配慮がより一層望まれるものと考えられる。むた， $\mathrm{O}$ -157やサルモネラ菌などによる食中毒を発生させない安 全な給食の実施も強く求められている。

我々はこれまで, 郷土料理の構造解析 $\left.{ }^{21} 23\right)$, 事業所 給食献立の構造解析 ${ }^{24,25)}$ といった主に成人を対象にした 食事献立を分析し，報告してきた。しかし先に述べたよ うな社会的な状況を考えると，成長期の子どもの食事は 非常に重要なものであるといえる。したがって，今後は 子ぞもの食事について分析していきたいと考えている。 今回はその第 1 段階として，学校給食献立の現状を把握 したいと考え, 山形県Y市で実施された小学校給食献立 の使用食品および調理方法を中心に構造解析を行ったの で報告する。

\section{2. 方 法}

\section{（1）資料}

小学校給食献立の構造解析に用いた資料は, 山形県 $\mathrm{Y}$ 市教育委員会発行の「学校保健の実態と今後の課題 平 成元年度」,「同 6 年度」,「同10年度」抢よび，小学校給 食献立平成元年度 (1989年), 平成 6 年度 (1994年), 平 成10年度（1998年）の 3 年間分である。Y市では18小学 校に給食室が設置され，給食室のない分校には本校から 給食を配送しているが，基本的には自校方式の学校給食 を行っている。献立は学校栄養職員が月に 1 回, 献立作 成会議を行い決定している。平成 5 年度以前は, 米飯給 食回数に応じて 4 種類の献立を作成していたが，平成 5 年度からは，米飯回数を統一し，1 種類の献立を用いた 「市内統一献立」で給食を実施するようになった。また， 平成 8 年に発生したO-157食中毒による影響で, 献立内 容に変化が生じたのではないかと考え, 平成元年度と6 年度，10年度の 3 年間を資料とすることとした。

\section{（2）児童数および給食実施校}

前述の「学校保健の実態と今後の課題」を用いて, 児 童数および給食実施校数の変化を調べた。

\section{(3) 献立数, 献立種類数および栄養価}

平成元年度は最も契食数の多かった米飯週 2 回の献立 表加, 平成 6 年度と 10 年度は米飯週 3 回の献立表から, 献立実施日数を全体の献立数として数え, さらに米飯給 食実施日数とパン給食実施日数に分類し，年度ごとおよ び月ごとに集計した。なお，うどんなどの湎類はパン給 食にあたる曜日に月 1 回実施されていたことと, 麺類と 共に，ハーフパン（通常より小さいパン）が添えられて いる場合が多く認められたので，パン給食として集計を 行った。むた献立内容を,「和風献立」「洋風献立」「中 華風献立」そのどれにもあてはまらない「その他の献立」 の 4 種類に分類し，同様に年度ごとおよび月ごとに集計 した．また栄責摂取量についても，年度および月ごとに 集計し， 3 年分を比較した。

\section{（4）使用食品数および食品使用量}

(3)と同様の献立表をもとに，延べの料理数および延べ の使用食品数, 延べの食品使用量を年度および月ごとに 集計し， 1 献立当りの料理数， 1 献立当りの食品数, 1 料理当りの食品数をそれぞれ算出した。なお料理数につ いては，牛乳，パンなどはそれぞれ 1 料理とし，カレー ライスや親子井のような場合は，ごはんと具の 2 つを合 わせて 1 料理として集計を行った。また使用食品につい ては，食品群および食品ごとにも使用回数を集計し，出 現率を算出した。さらに使用された食品の使用量を食品 群および食品ごとに集計し，1 回当りの平均使用量を算 出した。またメ二ュー（主食, 主菜, 汁物, 副菜, 飲み 物，デザート）ごとに分類して，1 回当りの平均使用量 も算出した。なお，食品群は四訂日本標準食品成分表の 区分にしたがって分類し，成分表に揭載されていない食 品については「その他」とした。また野菜類のみ, 緑黄 色野菜と淡色野菜に細分化して分類を行った。

\section{(5) 調理方法}

(4)で抽出した料理ごとに，「洗う」「切る」などの下処 理を除く，「揚げる」「炒める」といったその料理におけ る主要な調理操作を 1 つあげ，それを調理方法として年 度および月ごとに集計を行った。なお，牛乳やカップゼ リー，スライスチーズなどは「調理なし」として分類し， 果物や付合わせのトマトのように，洗って切っただけの 下処理のみのものは「生もの」として分類集計を行った。 
表 1 児童数および給食実施校数と米飯給食回数の変化

\begin{tabular}{c|rr|rr|rr}
\hline 週間米飯 & \multicolumn{2}{|c|}{ 平成元年度 } & \multicolumn{2}{|c|}{ 平成 6 年度 } & \multicolumn{2}{c}{ 平成 10 年度 } \\
\cline { 2 - 7 } 回数 (回) & 学校数 & 児童数 (人) & 学校数 & 児童数 (人) & 学校数 & 㛜童数 (人) \\
\hline 0 & 2 & 1,802 & 0 & 0 & 0 & 0 \\
2 & 11 & 5,141 & 0 & 0 & 0 & 0 \\
3 & 10 & 795 & 23 & 7,091 & 22 & 6,461 \\
4 & 1 & 17 & 1 & 8 & 0 & 0 \\
5 & 2 & 17 & 1 & 11 & 2 & 11 \\
\hline 合 計 & 26 & 7,772 & 25 & 7,110 & 24 & 6,472 \\
\hline
\end{tabular}

全校で米飯給食が実施できるように なり，献立を 1 種類に統一できるよ うになった。なお，米飯 5 回の小学 校は，山間部にある分校で，パンの 配送が経費その他の面から困難であ るため，他校がパン給食の日でも， 米飯を含めすべてを自校調理して米 飯給食を実施していた。統一献立に なる以前は米飯 4 回の献立にしたが
表 2 献立の種類の比較

\begin{tabular}{c|rrr|rrr|rrr}
\hline \multirow{2}{*}{} & \multicolumn{3}{|c|}{ 平成元年度 } & \multicolumn{3}{|c|}{ 平成 6 年度 } & \multicolumn{3}{c}{ 平成10年度 } \\
\cline { 2 - 9 } & 全体 & パン & 米飯 & 全体 & パン & 米飯 & 全体 & パン & 米飯 \\
\hline 献立数 & 197 & 116 & 81 & 198 & 81 & 117 & 198 & 79 & 119 \\
\hline 和風 & 83 & 18 & 65 & 103 & 8 & 95 & 97 & 7 & 90 \\
洋風 & 72 & 63 & 9 & 64 & 51 & 13 & 70 & 54 & 16 \\
中華風 & 37 & 31 & 6 & 29 & 20 & 9 & 29 & 16 & 13 \\
その他 & 5 & 4 & 1 & 2 & 2 & 0 & 2 & 2 & 0 \\
\hline
\end{tabular}

表 3 栄養摂取量の変化

\begin{tabular}{|c|c|c|c|c|c|}
\hline & 基準1) & 平成元年度 & 平成 6 年度 & 基準 ${ }^{2)}$ & 平成 10 年度 \\
\hline エネルギー（kcal） & 640 & 645.4 & 628.1 & 640 & 607.2 \\
\hline タンパク質（g） & 25 & 26.3 & 24.8 & 25 & 24.2 \\
\hline 脂質（g） & 21以下 & 20.8 & 19.1 & $18 \sim 25$ & 18.9 \\
\hline エネルギー比率（\%) & 30以下 & 29.0 & 27.4 & 25 35以下 & 28.0 \\
\hline カルシウム $(\mathrm{mg})$ & 290 & 340.1 & 328.7 & 290 & 315.7 \\
\hline 鉄（mg） & 3.2 & 3.21 & 2.80 & 3.2 & 2.91 \\
\hline ビタミンA（IU） & 675 & 1035.4 & 983.9 & 675 & 898.8 \\
\hline ビタミン $\mathrm{B}_{1}(\mathrm{mg})$ & 0.40 & 0.586 & 0.541 & 0.40 & 0.487 \\
\hline ビタンミ $\mathrm{B}_{2}(\mathrm{mg})$ & 0.55 & 0.642 & 0.659 & 0.55 & 0.564 \\
\hline ビタミンC（mg） & 22 & 30.2 & 29.8 & 22 & 15.7 \\
\hline 食塩相当量 (g) & 4.0以下 & 2.78 & 2.55 & 4.0 以下 & 2.74 \\
\hline
\end{tabular}

1) 昭和 61 年改正学校給食の平均栄養所要量の基準（児童 $8 \sim 9$ 歳）

2) 平成 7 年改正学校給食の平均栄湌所要量の基準（児童 $8 \sim 9$ 歳）
って給食を実施しており，セルフサンドイッチなど の, 米飯では対応しきれない献立のみ, 献立の変更 を行っている。また, 米飯 4 回の小学校も分校であ るが, 5 回の小学校よりは平野部にあることから, 本校より主食以外のものを配送してもらい，本校が パン給食の日でも自校炊飯を行って米飯給食を実施 していた。分校の児童は週 1 回, 本校に登校してパ ン給食をとることから，米飯が 4 回になっている。

このように, 献立が 1 種類に なったことで栄養士が献立作成 にかける時間や労力が軽減さ れ，献立内容を充実しやすくな った。なた食教育にもより多く の時間がかけられるようになる という利点も生まれた。さらに, 食材購入においても，全校分の 一括購入が可能となり，一括購 入分の発注業務を教育委員会栄 養士が行うようになったため, 学校栄養士の発注業務も軽減さ れた。

\section{3. 結果および考察}

\section{（1）巟童数および給食実施校数の比較}

児童数抢よび給食実施校数を米飯給食回数で比較した 結果を表 1 に示した。

その結果, 児童数, 給食実施校数ともに減少して抢り, Y市においても少子化が進んでいることが明らかになっ た。給食実施校が減少したのは, 児童数の減少により, 分校が閉校になったことによる。平成 5 年以前は自校炊 飯を実施していたため, 児童数の多い2つの小学校で米 飯給食が実施できず， 4 種類の献立（米飯 0 回, 2 回, 3 回，4回）を栄養士が毎月作成していた。しかし, 平 成 5 年以降は, 米飯 4 回と 5 回の学校以外は自校炊飯を 中止し, 米飯を業者委託に切り替えた。このことにより,

\section{（2）献立数, 献立の種類および栄養摂取量の比較}

献立数（給食実施日数）および献立の種類数の比較を 表 2 に，栄養拱取量の比較を表 3 にそれぞれ示した。

その結果, 献立数は 3 年間でほとんど変化が認められ なかった。献立の種類については，どの年度も全体的に は和風献立が $42 \sim 52 \%$ と約半数を占めたが，米飯給食の 日に $78 \% ， 92 \% ， 93 \%$ と高く，パン給食の日は洋風献立 が $88 \% ， 80 \% ， 77 \%$ ，中華風献立が $84 \% ， 69 \% ， 55 \%$ と 多くなっていた。パン給食の実施日の中には，麺類を主 食とした給食も含をれているが，曙類給食は，月に 1 回 実施されていた。その献立内容は, 米飯給食で和風献立 が多く実施されていることに配慮し，スパゲティやビー フンなど, 洋風や中華風の献立で実施されることが多く なっていた。 
表 4 献立数と使用食品数の変化

\begin{tabular}{|c|c|c|c|c|c|c|c|c|c|}
\hline & \multicolumn{3}{|c|}{ 平成元年度 } & \multicolumn{3}{|c|}{ 平成 6 年度 } & \multicolumn{3}{|c|}{ 平成10年度 } \\
\hline & 全体 & パン & 米飯 & 全体 & パン & 米飯 & 全体 & パン & 米飯 \\
\hline 献立数 & 197 & 117 & 80 & 198 & 81 & 117 & 198 & 79 & 119 \\
\hline 料理数 & 903 & 551 & 352 & 939 & 396 & 543 & 921 & 386 & 535 \\
\hline 1 献立当り料理数 1$)$ & 4.6 & 4.7 & 4.4 & 4.7 & 4.9 & 4.6 & 4.7 & 4.9 & 4.5 \\
\hline 食品数 & 4,442 & $2,706 \quad 1$ &, 736 & 4,606 & 1,998 &, 608 & 4,540 & 1,888 & 652 \\
\hline 1 献立当り食品数 2$)$ & 22.3 & 23.1 & 21.2 & 23.2 & 24.6 & 22.2 & 23.0 & 23.8 & 22.4 \\
\hline 1 料理当り食品数 3$)$ & 4.8 & 4.9 & 4.8 & 4.9 & 5.0 & 4.8 & 4.9 & 4.9 & 5.0 \\
\hline
\end{tabular}

1) 1 献立当り料理数 : 料理数 / 献立数

2) 1 献立当り食品数 : 食品数/献立数

3) 1 料理当り食品数 : 食品数 / 料理数

表 5 使用食品数の変化（食品群）

\begin{tabular}{|c|c|c|c|c|c|c|}
\hline & \multicolumn{2}{|c|}{ 平成元年度 } & \multicolumn{2}{|c|}{ 平成 6 年度 } & \multicolumn{2}{|c|}{ 平成10年度 } \\
\hline & 使用回数 & 出現率 $(\%) *$ & 使用回数 & 出現率 $(\%)$ & 使用回数 & 出現率 (\%) \\
\hline 穀類 & 273 & 6.15 & 273 & 5.93 & 263 & 5.79 \\
\hline いも及びデンプン類 & 195 & 4.39 & 191 & 4.15 & 187 & 4.12 \\
\hline 砂糖及び甘味料 & 96 & 2.16 & 110 & 2.39 & 95 & 2.09 \\
\hline 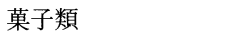 & 6 & 0.14 & 5 & 0.11 & 12 & 0.26 \\
\hline 油脂類 & 225 & 5.07 & 232 & 5.04 & 231 & 5.09 \\
\hline 種実類 & 44 & 0.99 & 49 & 1.06 & 53 & 1.17 \\
\hline 豆類 & 181 & 4.07 & 220 & 4.78 & 215 & 4.74 \\
\hline 魚介類 & 176 & 3.96 & 181 & 3.93 & 180 & 3.96 \\
\hline 獣鳥鯨肉類 & 243 & 5.47 & 222 & 4.82 & 221 & 4.87 \\
\hline 卵類 & 78 & 1.76 & 78 & 1.69 & 58 & 1.28 \\
\hline 乳類 & 268 & 6.03 & 271 & 5.88 & 261 & 5.75 \\
\hline 緑黄色野菜 & 501 & 11.28 & 489 & 10.62 & 549 & 12.09 \\
\hline 淡色野菜 & 761 & 17.13 & 775 & 16.82 & 687 & 15.13 \\
\hline 果実類 & 160 & 3.60 & 140 & 3.04 & 105 & 2.31 \\
\hline きのこ類 & 148 & 3.33 & 138 & 3.00 & 133 & 2.93 \\
\hline 海藻類 & 77 & 1.73 & 89 & 1.93 & 77 & 1.70 \\
\hline 嗜好飲料類 & 205 & 4.62 & 273 & 5.93 & 329 & 7.25 \\
\hline 調味料及び香辛料 & 733 & 16.50 & 773 & 16.78 & 778 & 17.14 \\
\hline 調理加工食品類 & 71 & 1.60 & 93 & 2.02 & 105 & 2.31 \\
\hline その他 & 1 & 0.02 & 4 & 0.08 & 1 & 0.02 \\
\hline 合 計 & 4,442 & 100.00 & 4,606 & 100.00 & 4,540 & 100.00 \\
\hline
\end{tabular}

$*$ 出現率 : (使用回数 $/$ 使用回数の合計) $\times 100$

栄養摂取量については, 概ね基準量を充足していたが, エネルギー，タンパク質，鉄分については，平成10年度 が最も低くなっており，摂取栄養量が減少する傾向が認 められた。使用食品数や種類は, 平成元年度よりも 6 年 度と 10 年度の方が多くなっていたことから，エネルギー や鉄分の摂取栄養量の減少は，表 7 に示した合計の食品 使用量の減少に起因するものと推測される。栄養士が残 食に配慮し, 食品使用量を調整しているものとも考えら れるが，成長期の児童には，タンパク質や鉄分は重要な 栄養素であることから，タンパク質や鉄分の多い食品を 選択すること，またその使用量などについて今後配慮が 必要であると考える。現在集計中ではあるが，平成11年 表 8 にそれぞれ示した。
度以降の献立におい ては,レバーや貝類, 海藻などを多く取り 入れるようになって おり，鉄分について は, 改善の傾向にあ るといえる。

Y市の献立におい ては和風献立が多 く, 米飯給食回数の 増加した平成 5 年以 降の平成 6 年度と 10 年度 の献立では元年度に比較 して和風献立が増加して いた。一般的に和食は洋 食にくらべて食塩摂取量 が多くなる傾向にあるこ とから，このような和風 献立の増加に伴い, 食塩 摂取量の増加が推測され たが，食塩摂取量はむし ろ低く抑えられていた。 これらの結果を考え合わ せると，栄養士が献立を 作成する際, 児童の家庭 での脂質や食塩などの過 剰摂取に配慮して, 献立 内容をかなり工夫してい ることが推測できた。

（3）使用食品数および食 品使用量の比較

全体の使用食品数の変

化については表 4 に示し, 食品群ごとの比較を表 5 に, 食品ごとの比較を表 6 に示した。また, 食品使用量につ いては, 食品群ごとの比較を表 7 に, 食品ごとの比較を

その結果, 表 4 より, どの年度も 1 つの献立が $22 \sim 25$ の食品を使用して，4.4４.90料理で構成されているこ とが明らかになった.しかし，米飯とパン給食を比較す ると, パン給食の方が料理数, 食品数ともに多くなる傾 向が認められた．これは，米飯給食ではカレーライス， 親子井といった主食と主菜を組合せたものが多く，パン 給食では，セルフサンドイッチのように，主菜や副菜を 各児童が自由に楽しみながら，パンにはさんで食べられ 
表 6 使用食品数の変化

\begin{tabular}{|c|c|c|c|c|c|c|c|c|c|c|c|c|c|}
\hline \multicolumn{4}{|c|}{ 平成元年度 } & \multicolumn{5}{|c|}{ 平成 6 年度 } & \multicolumn{5}{|c|}{ 平成 10 年度 } \\
\hline 食品名 & 使用回数 & 出現率(\%) & 果積率(\%) & 順位 & 食品名 & 使用回数 & 出現率(\%) & 果積率(\%) & 順位 & 食品名 & 使用回数 & 出現率 $(\%)$ & 果積率(\%) \\
\hline にんじん & 257 & 5.79 & - & 1 & しょうゆ & 263 & 5.71 & - & 1 & しょうゆ & 278 & 6.12 & - \\
\hline しょうゆ & 231 & 5.20 & 10.99 & 2 & にんじん & 244 & 5.30 & 11.01 & 2 & にんじん & 270 & 5.95 & 12.07 \\
\hline 牛乳 & 214 & 4.82 & 15.80 & 3 & 牛乳 & 215 & 4.67 & 15.68 & 3 & 酒 & 216 & 4.76 & 16.83 \\
\hline 食塩 & 206 & 4.64 & 20.44 & 4 & 食塩 & 213 & 4.62 & 20.30 & 4 & 牛乳 & 213 & 4.69 & 21.52 \\
\hline 植物油 & 158 & 3.56 & 24.00 & 5 & 酒 & 164 & 3.56 & 23.86 & 5 & 食塩 & 199 & 4.38 & 25.90 \\
\hline 酒 & 134 & 3.02 & 27.01 & 6 & 植物油 & 161 & 3.50 & 27.36 & 6 & 植物油 & 146 & 3.22 & 29.12 \\
\hline たまねぎ & 128 & 2.88 & 29.90 & 7 & たまねぎ & 130 & 2.82 & 30.18 & 7 & こしょう & 126 & 2.78 & 31.89 \\
\hline キャベツ & 103 & 2.32 & 32.22 & 8 & 精白米 & 116 & 2.52 & 32.70 & 8 & 精白米 & 118 & 2.60 & 34.49 \\
\hline こしょう & 94 & 2.12 & 34.33 & 9 & こしょう & 105 & 2.28 & 34.98 & 9 & たまねぎ & 115 & 2.53 & 37.03 \\
\hline きゅうり & 92 & 2.07 & 36.40 & 10 & 砂糖 & 103 & 2.24 & 37.21 & 10 & 砂糖 & 84 & 1.85 & 38.88 \\
\hline 豚肉 & 85 & 1.91 & 38.32 & 11 & きゅうり & 98 & 2.13 & 39.34 & & キャベツ & 84 & 1.85 & 40.73 \\
\hline 砂糖 & 84 & 1.89 & 40.21 & 12 & キャベツ & 86 & 1.87 & 41.21 & 12 & みりん & 78 & 1.72 & 42.44 \\
\hline 食パン & 81 & 1.82 & 42.03 & 13 & ねぎ & 82 & 1.78 & 42.99 & 13 & みそ & 73 & 1.61 & 44.05 \\
\hline 精白米 & 80 & 1.80 & 43.83 & 14 & みりん & 81 & 1.76 & 44.75 & & ねぎ & 73 & 1.61 & 45.66 \\
\hline 干しいたけ & 77 & 1.73 & 45.57 & 15 & みそ & 76 & 1.65 & 46.40 & 15 & 豚肉 & 72 & 1.59 & 47.25 \\
\hline ねぎ & 73 & 1.64 & 47.21 & 16 & 豚肉 & 70 & 1.52 & 47.92 & 16 & しょうが & 70 & 1.54 & 48.79 \\
\hline 鷄卵 & 70 & 1.58 & 48.78 & & しょうが & 70 & 1.52 & 49.44 & 17 & でんぷん & 63 & 1.39 & 50.18 \\
\hline じゃがいも & 61 & 1.37 & 50.16 & 18 & 鶏肉 & 69 & 1.50 & 50.93 & 18 & もやし & 62 & 1.37 & 51.54 \\
\hline 豆腐 & 59 & 1.33 & 51.49 & 19 & でんぷん & 68 & 1.48 & 52.41 & 19 & 豆腐 & 61 & 1.34 & 52.89 \\
\hline 慆肉 & 56 & 1.26 & 52.75 & & 豆腐 & 68 & 1.48 & 53.89 & 20 & 鵎肉 & 60 & 1.32 & 54.21 \\
\hline しょうが & 56 & 1.26 & 54.01 & 21 & 酢 & 66 & 1.43 & 55.32 & 21 & 干しいたけ & 56 & 1.23 & 55.44 \\
\hline でんぷん & 54 & 1.22 & 55.22 & 22 & 食パン & 60 & 1.30 & 56.62 & 22 & ほうれん草 & 55 & 1.21 & 56.65 \\
\hline みそ & 52 & 1.17 & 56.39 & 23 & 鶏肉 & 57 & 1.24 & 57.86 & 23 & 食パン & 54 & 1.19 & 57.84 \\
\hline たけのこ & 52 & 1.17 & 57.56 & 24 & じゃがいも & 52 & 1.13 & 58.99 & & 鶏鳥 & 54 & 1.19 & 59.03 \\
\hline みりん & 48 & 1.08 & 58.64 & & 干しいたけ & 52 & 1.13 & 60.12 & 25 & じゃがいも & 52 & 1.15 & 60.18 \\
\hline : & : & : & & & : & : & : & & & : & $\cdot$ & : & : \\
\hline いか & 20 & 0.45 & 80.32 & 57 & みかん & 19 & 0.41 & 80.03 & 53 & ピーマン & 20 & 0.44 & 80.13 \\
\hline 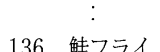 & : & : & & & : & : & : & & & & : & : & \\
\hline 136 鮭フライ & 1 & 0.02 & 100.00 & 166 & あられ & 1 & 0.02 & 100.00 & & あじっこ & 1 & 0.02 & 100.00 \\
\hline 合 計 & 4,442 & 100.00 & & 合 & 合 計 & 4,606 & 100.00 & & & 計 & 4,540 & 100.00 & \\
\hline
\end{tabular}

るように工夫したメニューがみられ，パンにはさむ各食 品の種類を 1 料理として集計したことから, 料理数や食 品数が多くなったものと考えられた.

使用食品回数にについては, まず表 5 より, どの年度 においても, ほとんどの料理に味付けに使用される調味 料, 野菜類の使用回数抢よび出現率が高いことが明らか になった．また，魚介類と比較して肉類の使用回数およ び出現率が多くなっていた。これはやはり児童の嗜好を 考慮したものと考えられるが, 表 2 で示したように, 献 立数（給食実施日数）が197〜 198であることから，魚介 類も肉類も 1 日, 1 回程度は使用されていたことになり, 1 日の使用回数にそれ程差がなかったことから，児童の 嗜好を考慮しつつも，魚介類を献立に取入れようとして いる栄養士の工夫が同えると考えられる.このことは, 年々, 肉類の使用回数が減少していることからも明らか である、また, 表 5 に抢いて, 喍好飲料類と調理加工食
品類の使用回数の増加が顕著に認められるが, 嘫好飲料 については,「酒」や「ワイン」の使用回数の増加によ るものであり, 調理加工食品類については, 「鮭フライ」 などの冷凍食品の増加によるものと考えられる.

個々の食品の使用回数を表 6 に示したが, 個々の食品 の使用回数を合計使用回数で除したものを出現率として 表し, 出現率の累積を累積率として表した. 出現率は全 体の給食におけるその食品の使用割合が理解でき, 累積 率によって，献立がどんな食品によって多く構成されて いたかが理解できると考え表を作成した，表 6 より，ど の年度も上位に出現した食品は調味料, 野菜類が多く, その種類には大きな変化は認められなかった。しかし， 平成元年度は米飯 2 回, 6 年度と 10 年度は米飯 3 回の献 立を資料としたため,「精白米」と「パン類」の使用回 数に違いが認められた. 元年度13位だった「食パン」が 6 年度では 22 位, 10 年度は 23 位になり, 逆に「精白米」 
表 7 食品使用量の变化（食品群）

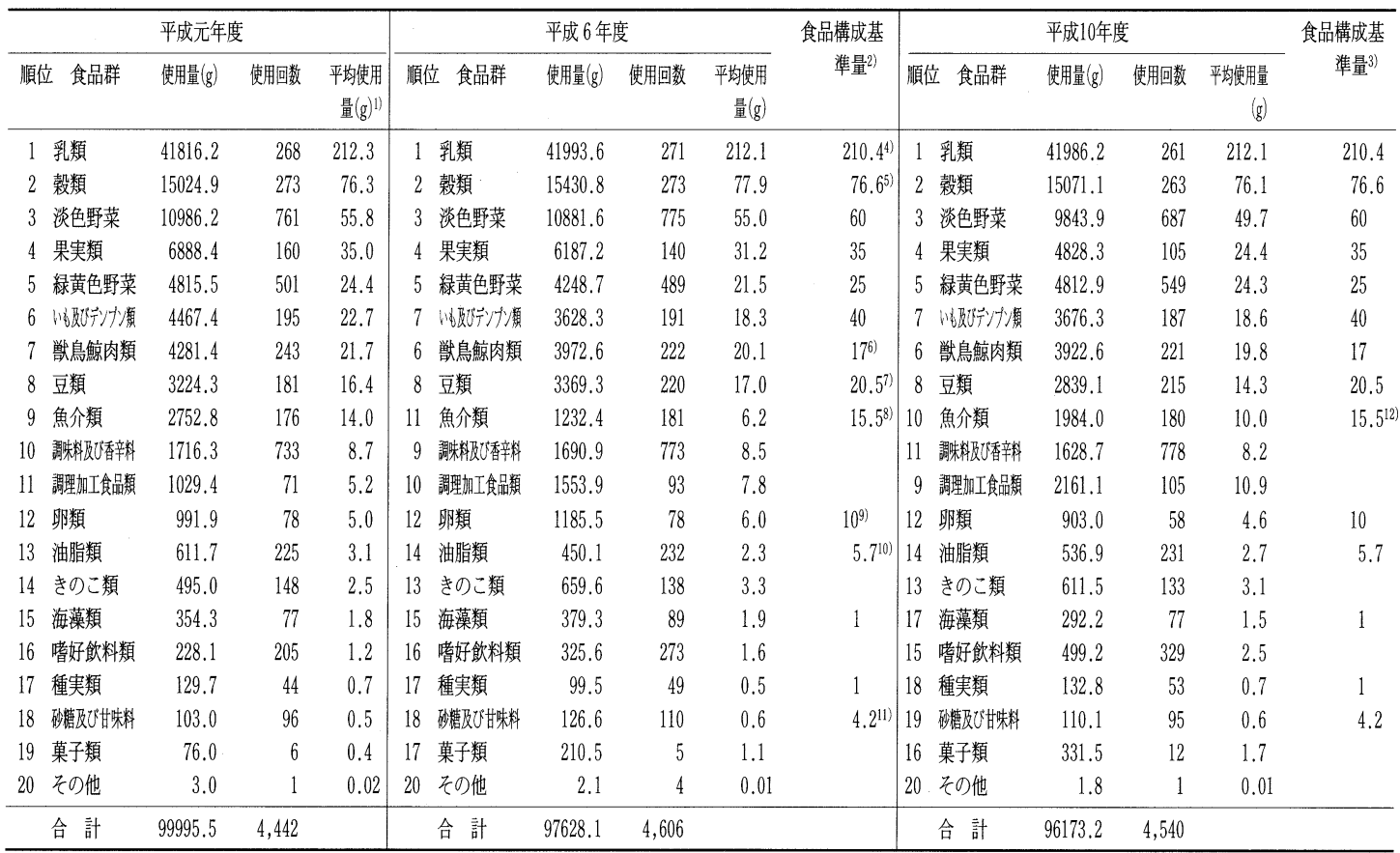

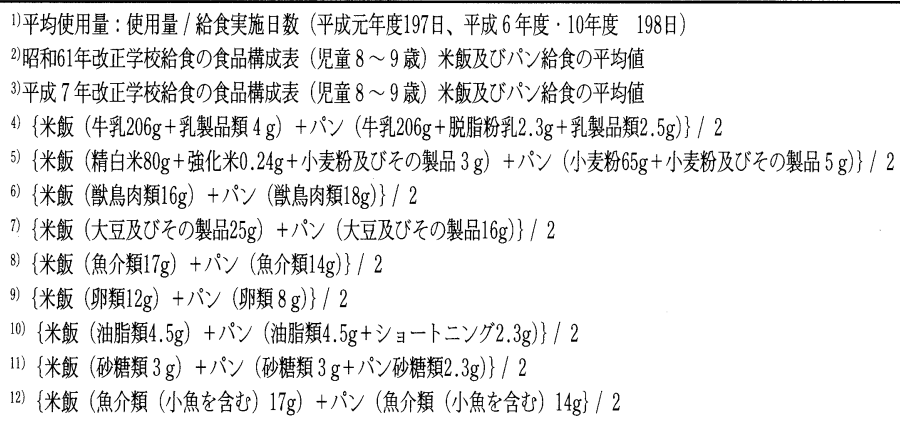

は元年度の 14 位から 6 年度, 10 年度は 8 位になった。さ らに，元年度 23 位の「反そ」が 6 年度は 15 位，10年度は 13位となったことから, 米飯回数が増えたことによって, みそ汁などへの使用が増加したものと考えられる．累積 率をみると，ぞの年度も17ないしは18位で $50 \% ， 53 \sim 59$ 位で $80 \%$ に達しており，これらのことから献立が概ね上 位の18位までの食品を中心に，53～59種類の食品の組合 せで構成されていたといえる。 また表 6 には示していな いが，使用回数 $1 \sim 2$ 回の食品には，「雪菜」「菜の花」 「鯉」「柏餅」「ひなあられ」など, 旬の素材, 郷土特有 の食品や節句にちなんだ食品などが月ごとに確実に使用 されており，季節感や食育にも配慮がなされていること が明らかになった。
食品群別の使用量は表 7 に, 使用量を献立数（給食実 施日数) で除して, 学校給食の食品構成表を基準量とし て比較して示した. その結果, 乳類と穀類, 肉類は基準 量を充足していたが, イモ類, 豆類, 魚介類, 油脂類, 砂糖類の使用量が少ないことが明らかになった．1モ類 については, 基準量 $40 \mathrm{~g}$ に対して $22.7,18.3,18.6 \mathrm{~g}$ と $50 \%$ 程度の充足率であり，豆腐は， $20.5 \mathrm{~g}$ の基準量に対 して $16.4,17.0,14.3 \mathrm{~g}$ と70 80\%程度の充足率, 魚 介類は, $15.5 \mathrm{~g}$ の基準量に対して $14.0,6.2,10.0 \mathrm{~g}$ の 使用量となって抢り, 特に, 平成 6 年度は充足率 $40 \%$ と 非常に低いものであった，しかし，魚介類については， エビフライや鮭フライなど一括購入による冷凍食品のよ うな加工食品が多く使用されており，これらを調理加工 
表 8 食品使用量の変化

\begin{tabular}{|c|c|c|c|c|c|c|c|c|c|c|c|c|c|c|}
\hline \multicolumn{5}{|c|}{ 平成元年度 } & \multicolumn{5}{|c|}{ 平成 6 年度 } & \multicolumn{5}{|c|}{ 平成 10 年度 } \\
\hline 順位 & 食品名 & 使用量 $(\mathrm{g})$ & 使用回数 & 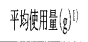 & 順位 & 食品名 & 使用量 $(\mathrm{g})$ & 使用回数 & 正为潒用量(g) & 順位 & 亡 食品名 & 使用量 $(\mathrm{g})$ & 使用回数 & 平堆用量 $(\mathrm{g})$ \\
\hline 1 & 牛乳 & 42019.0 & 218 & 192.7 & 1 & 牛乳 & 42310.2 & 220 & 192.3 & 1 & 牛乳 & 42209.5 & 217 & 194.5 \\
\hline 2 & 精白米 & 6000.0 & 80 & 75.0 & 2 & 精白米 & 8700.0 & 116 & 75.0 & 2 & 精白米 & 8850.0 & 118 & 75.0 \\
\hline 3 & パン & 5557.0 & 79 & 70.3 & 3 & パン & 3920.0 & 60 & 65.3 & 3 & パン & 3150.0 & 42 & 75.0 \\
\hline 4 & たまねぎ & 2710.0 & 127 & 21.3 & 4 & じゃがいも & 2475.0 & 61 & 40.6 & 4 & たまねぎ & 2380.9 & 111 & 21.4 \\
\hline 5 & じゃがいも & 2581.0 & 60 & 43.0 & 5 & たまねぎ & 2474.7 & 124 & 20.0 & 5 & じゃがいも & 2169.0 & 51 & 42.5 \\
\hline 6 & キャベツ & 2561.0 & 110 & 23.3 & 6 & 豆腐 & 2251.2 & 88 & 25.6 & 6 & キャベツ & 2043.0 & 84 & 24.3 \\
\hline 7 & 豆腐 & 2430.0 & 59 & 41.2 & 7 & にんじん & 1924.5 & 199 & 9.7 & 7 & にんじん & 1845.8 & 241 & 7.7 \\
\hline 8 & にんじん & 2201.8 & 245 & 9.0 & 8 & キャベッ & 1898.1 & 84 & 22.6 & 8 & 豆腐 & 1746.0 & 60 & 29.1 \\
\hline 9 & みかん & 1891.0 & 26 & 72.7 & 9 & 豚肉 & 1423.8 & 73 & 19.5 & 9 & 豚肉 & 1639.1 & 62 & 26.4 \\
\hline \multirow[t]{2}{*}{10} & 豚肉 & 1766.0 & 86 & 20.5 & 10 & 䊿肉 & 1305.5 & 74 & 17.6 & 10 & 鷄肉 & 1549.5 & 64 & 24.2 \\
\hline & : & : & : & & & : & : & : & : & & : & : & & $:$ \\
\hline \multirow[t]{2}{*}{20} & しょうゆ & 683.0 & 181 & 3.8 & 19 & しょうゆ & 719.1 & 199 & 3.6 & 16 & しょうゆ & 743.0 & 240 & 3.1 \\
\hline & : & : & : & & & : & : & : & : & & : & : & & : \\
\hline \multirow[t]{2}{*}{29} & 植物油 & 426.3 & 135 & 3.2 & 29 & ケチャップ & 386.3 & 20 & 19.3 & 27 & 植物油 & 339.3 & 134 & 2.5 \\
\hline & : & : & & & & : & : & : & : & & : & : & & : \\
\hline \multirow[t]{2}{*}{37} & ケチャップ & 314.7 & 38 & 8.3 & 31 & 植物油 & 349.1 & 144 & 2.4 & 29 & ケチャップ & 327.3 & 30 & 10.9 \\
\hline & : & : & : & : & & : & : & : & : & & : & : & $:$ & : \\
\hline \multirow[t]{2}{*}{50} & パターロール & 212.0 & 5 & 42.4 & 50 & ぶどう & 200.0 & 2 & 100.0 & 50 & すいか & 180.0 & 3 & 60.0 \\
\hline & : & : & $:$ & : & & : & : & : & : & & : & : & $:$ & : \\
\hline 100 & ツナ缶 & 90.0 & 6 & 15.0 & 100 & バナナ & 80.5 & 4 & 20.1 & 100 & 春雨 & 84.6 & 14 & 6.0 \\
\hline & 味付计小魚 & 11.0 & 3 & 3.7 & 200 & カリフラワー & 13.5 & 1 & 13.5 & 200 & 貝柱水煮缶 & 22.5 & 2 & 11.3 \\
\hline & : & : & $:$ & : & & : & : & $:$ & & & : & : & $:$ & : \\
\hline & : & : & : & : & & : & : & : & : & & : & : & : & : \\
\hline \multirow[t]{2}{*}{236} & ゆずの皮 & $\phi^{2)}$ & 1 & $\phi$ & 262 & ナツメグ & $\phi$ & 1 & $\phi$ & 298 & ナツメグ & $\phi$ & 1 & $\phi$ \\
\hline & 合 計 & 99995.5 & 4,442 & & 合 & 今 計 & 97628.1 & 4,606 & & & 合 計 & 96173.2 & 4,540 & \\
\hline
\end{tabular}

1) 平均使用量 : 使用量 $(\mathrm{g}) /$ 使用回数

2) $\phi$ : 使用量 $0.1 \mathrm{~g}$ 末満

食品類として分類したため，このような結果になったも のと考えられた.

個々の食品の使用量については表 8 に，使用量を使用 回数で除して 1 回当りの平均使用量を算出して示した. この結果, 上位に出現した食品は 3 年間で大きな変化は 認められなかった。 また使用回数とは異なり，使用量に おいては，主食や主菜に使用されやすい食品である「精 白米」「パン」「豚肉」や，「じゃがいも」のように使用 回数は少ないが 1 回の使用量の多い食品などが上位を占 め, 1 回の使用量が $0.1 \mathrm{~g}$ 以下の香辛料, 調味料などが 下位に並ぶ結果となった．このことから，使用回数で上 位を占めた食品が必ずしも使用量の上位を占めるわけで はないことが明らかになった。上位に「豚肉」「鵎肉」 の肉類は出現したが，魚介類が出現しなかった．これは， 肉類は豚，牛，鵎と種類が少ない上，その形状もブロッ ク，挽肉など様々あり，広範囲に使用されていたことか ら, 使用量, 使用回数ともに多くなっていた. 一方魚介
類は, 肉類に比較して種類が多く, 1 回の平均使用量は 「さば」 $45 \mathrm{~g}$,「あじ」 $45 \mathrm{~g}$ と多いものの, 合計の使用量, 使用回数が少ないため, 上位には出現してこなかった.

\section{(4) 調理方法の比較}

主要調理操作の比較を表 9 に示した. その結果, 平成 元年度は 11 種類, 6 年度と 10 年度は 13 種類の調理操作に 分類され, 合計の操作回数も増加していた.なお米飯に ついては，元年度は自校炊飯であったため「炊く」に分 類したが， 6 年度からは米飯は業者委託となったため 「業者委託」に分類した. また 6 年度からは元年度に出 現しなかった「茹でる」「炒る」が出現している.

この要因としては，まず第 1 に，平成 5 年以降，市内 統一献立を実施したことにより，栄養士の献立作成にか ける時間や労力が増加し, 献立に工夫やこれをでになか った新メニューが加えられたこと，さらには年々「生も の」の操作回数が減少していることと考え合せると，O -157食中毒の影響による，食品衛生面を考慮した加熱処 
表 9 主要調理操作の比較

\begin{tabular}{|c|c|c|c|c|c|c|c|c|c|c|c|c|c|c|}
\hline \multicolumn{5}{|c|}{ 平成元年度 } & \multicolumn{5}{|c|}{ 平成 6 年度 } & \multicolumn{5}{|c|}{ 平成10年度 } \\
\hline 順位 & 調理操作 & 操作回数 & 出現率(\%) & 累積率(\%) & 順位 & 調理操作 & 操作回数 & 出現率 (\%) & 累積率(\%) & 順位 & 調理操作 & 操作回数 & 出現率(\%) & 果積率(\%) \\
\hline 1 & 調理なし & 328 & 36.3 & - & 1 & 調理なし & 257 & 27.3 & - & 1 & 調理なし & 258 & 28.0 & - \\
\hline 2 & 煮る & 227 & 25.2 & 61.5 & 2 & 煮る & 239 & 25.5 & 52.8 & 2 & 煮る & 249 & 27.0 & 55.0 \\
\hline 3 & 和える & 109 & 12.1 & 73.6 & 3 & 和える & 123 & 13.1 & 65.9 & 3 & 業者委託 & 118 & 12.8 & 67.8 \\
\hline 4 & 生むの & 77 & 8.5 & 82.1 & 4 & 業者委託 & 116 & 12.4 & 78.3 & 4 & 和える & 115 & 12.5 & 80.3 \\
\hline 5 & 炊 < & 50 & 5.5 & 87.6 & 5 & 生もの & 75 & 7.9 & 86.2 & 5 & 生もの & 64 & 6.9 & 87.2 \\
\hline 6 & 揚げる & 48 & 5.3 & 92.9 & 6 & 揚げる & 40 & 4.3 & 90.5 & 6 & 揚げる & 45 & 4.9 & 92.1 \\
\hline 7 & 炒める & 36 & 4.0 & 96.9 & 7 & 炒める & 30 & 3.2 & 93.7 & 7 & 炒める & 41 & 4.5 & 96.6 \\
\hline 8 & 焼く & 10 & 1.1 & 98.0 & 8 & 漬ける & 22 & 2.3 & 96.0 & 8 & 浸す & 12 & 1.3 & 97.9 \\
\hline 9 & 漬ける & 9 & 1.0 & 99.0 & 9 & 蒸す & 13 & 1.4 & 97.4 & 9 & 蒸す & 7 & 0.8 & 98.7 \\
\hline 10 & 浸す & 7 & 0.8 & 99.8 & 10 & 焼く & 10 & 1.1 & 98.5 & 10 & 焼く & 6 & 0.7 & 99.4 \\
\hline 11 & 蒸す & 2 & 0.2 & 100.0 & 10 & 浸す & 10 & 1.1 & 99.6 & 11 & 茹でる & 4 & 0.4 & 99.8 \\
\hline & & & & & 12 & 炒る & 3 & 0.3 & 99.9 & 12 & 漬ける & 1 & 0.1 & 99.9 \\
\hline & & & & & & 茹でる & 1 & 0.1 & 100.0 & 12 & 炒る & 1 & 0.1 & 100.0 \\
\hline & 合 計 & 903 & 100.0 & & & 今 計 & 939 & 100.0 & & & 今 計 & 921 & 100.0 & \\
\hline
\end{tabular}

理作業の増加といったことがあげられる. 食品使用回数 との関連をみると，表 5 ・6 で「油脂類」「植物油」の 使用回数が上位にあった.これは単に「揚げる(揚げ物)」 「炒める (炒め物)」操作が多かったというだけではなく， サラダのドレッシングや酢の物などの風味付けに使用さ れるごま油など，「和える」操作にも多く使用されてい たことが推測された.

今後は, 小学校給食献立の地方比較, 中学校給食献立 などの構造解析を行い, 学校給食の実態を明らかにした いと考えている.

\section{4. 要 約}

山形県 $\mathrm{Y}$ 市で実施された小学校給食献立 3 年分（平成 元年度, 6 年度, 10 年度）を, 使用食品および調理方法 を中心に構造解析を行った。

1）比較した 3 年間で献立数（給食実施日数）にほ とんど違いはなかった．献立の種類はいずれの年 度も和風献立が約半数を占めていた，栄盖摂取量 は概ね基準量を充足していたが，エネルギー，タ ンパク質, 鉄分については, 基準量より少なかっ た.

2) いずれの年度も，1 献立当り平均して $22 \sim 25$ 個 の食品を使用し，4.4〜4.9の料理で構成されてい た. 使用回数の多い食品は調味料, 野菜類で, 使 用量の多い食品は「精白米」「パン」「豚肉」など 主食や主菜に使用される食品が上位を占めていた。

3 ) 平成元年度11種類の調理操作であったのに対し て， 6 年度と 10 年度は「茹でる」と「業者委託」
が加わり, 13種類に増加していた。

\section{謝 辞}

資料をご提供くださいました米沢市教育委員会学校教 育課土田良雄課長補佐, 山口里枝子栄養士に心より御礼 申し上げをす。

\section{文 献}

1）富岡和夫：給食管理実務ガイドブック，同文書院，東京， p.199（1998）

2）前川當子：給食管理，医歯薬出版，東京，p.78（1997）

3）厚生統計協会: 厚生の指標, 46, $379(2000)$

4）坂本元子：臨床栄養，87，32（1995）

5）渡部由美：栄盖学雑誌，47，31（1989）

6）緑川英子, 荒井富佐子, 田伏千代子：バイタル栄養指導論, 医歯薬出版, 東京, p.18 (1997)

7）日本子ぞも家庭総合研究所：日本子ぞも資料年鑑，6， 254 (1998)

8）厚生省保健医療局：国民栄盖の現状 平成10年国民栄養調 查結果，第一出版，東京， p. 30-32（2000）

9）厚生省公衆衛生局：国民栄養の現状 昭和58年度版，第一 出版, 東京, p. 108-109 (1983)

10）厚生省保健医療局: 国民栄養の現状 平成10年国民栄養調 查結果, 第一出版, 東京, p.105（2000）

11）文部省大臣官房調査統計企画課：学校保健統計調査報告書 昭和48年度, 大藏省印刷局, 東京, p.270（1972）

12）文部省大臣官房調查統計企画課：学校保健統計調查報告書 昭和52年度, 大藏省印刷局, 東京, p.184（1978）

13）文部省大臣官房調査統計企画課: 学校保健統計調查報告書 昭和54年度，大藏省印刷局，東京， p. 212（1980）

14）文部省大臣官房調査統計企画課：学校保健統計調査報告書 昭和58年度, 大藏省印刷局, 東京, p.70（1984）

15）文部省大臣官房調査統計企画課: 学校保健統計調查報告書 
昭和63年度，大蔵省印刷局，東京，p.120（1989）

16）文部省大臣官房調査統計企画課：学校保健統計調査報告書 平成 5 年度, 大蔵省印刷局, 東京, p.132（1994）

17）文部省: 学校保健統計調査報告書 平成 9 年度, 文部省, p.108（1998）

18）文部省: 学校保健統計調査報告書 平成11年度, 文部省, p.108 (1999)

19）日本子どもを守る会：子ども白書· 2000 年度版, 草土文化, 東京, p.132（2000）

20）正木健雄：おかしいぞ子どものからだ，大月書店，東京， p.25 (1995)
21）岡本順子, 加藤みゆき, 大森正司, 川端晶子, 佐々木敏雄 : 家政誌, 38, 425-430 (1987)

22）尾上とし子, 加藤みゆき, 田村朝子, 大森正司 : 栄養学雑 誌，51，215-219（1993）

23）矢野とし子, 小松真由美, 小松妙子, 岡本順子, 大森正司 : 平成 2 年度調理科学会講演要旨集, p. 9 , 東京 (1990)

24）田村朝子, 斎藤ひろみ, 尾上とし子, 加藤みゆき, 大森正 司：栄養学雑誌，54，129-133（1996）

25）田村朝子, 大森正司, 加藤みゆき, 矢野とし子 : 平成 4 年 度調理科学会講演要旨集, p.32, 東京 (1992) 